\title{
ANALISIS YURIDIS TERHADAP PENERAPAN HAK CIPTA SEBAGAI OBJEK JAMINAN FIDUSIA DALAM PEMBERIAN FASILITAS KREDIT PADA PERBANKAN DI KOTA BATAM
}

\author{
Agustianto ${ }^{1}$ \\ Yeny Sartika ${ }^{2}$
}

\begin{abstract}
The application of copyright as an object of fiduciary collateral in the world is still constrained by several obstacles. So that until now there are still no financial institutions that carry out these provisions. Because the financing institution has only received movable and tangible material objects that can be seen directly and have high economic value. This can guarantee the credit taker / debtor fulfills the performance in accordance with the credit agreement agreed upon by the parties. However, copyright regulations have allowed copyrights to be tied to fiduciaries. Because copyright contains elements of economic rights.

The research method used in the study is empirical, supported by the results of interviews with several speakers among notaries, lawyers and legal consultants, financial institutions (commercial banks and BPR), and the Regional Office of Menkumham, the primary data from this study. As well as to strengthen the opinions of the resource persons to disburse supporting data through library studies as secondary data. After collecting all the managed data and analyzing using a qualitative method that is classifying each data obtained in accordance with the research aspects. Finally draw conclusions by describing them descriptively.

Guided from this research the results obtained are copyright as objects of fiduciary security constrained by the absence of copyright as one of the collateral for loans in Bank Indonesia Regulations, and the Fiduciary Guarantee Act regarding the regulation of intangible moving objects is less significant. In addition, there is no valuation institution that serves to assess the economy owned by a copyright.
\end{abstract}

Keywords: banking, credit agreements, fiduciary guarantees, copyright

\footnotetext{
${ }^{1}$ Fakultas Hukum Universitas Internasional Batam

${ }^{2}$ Fakultas Hukum Universitas Internasional Batam
} 


\section{A. Latar Belakang}

Didalam dunia bisnis perbankan untuk memanfatkan fasilitas kredit yang diberikan oleh bank, tidak cukup hanya perjanjian kredit yang dibuat oleh para pihak. Melainkan diperlukan suatu jaminan yaitu objek kebendaan kepunyaan debitur, yang memiliki nilai ekonomis yang tinggi. Dengan adanya objek yang dijadikan jaminan tersebut maka kerditur/bank terasa lebih terjamin atas pinjaman yang diberikan. Serta kemungkinan debitur tidak melaksanakan kewajibannya dalam membayar pinjaman sangat kecil.

Pada umumnya yang menjadi dasar pegangan bank adalah hak atas tanah yang dilanjutkan dengan pemasangan hak tanggungan. Seiring dengan perkembangan zaman semakin pesat, kebendaan yang dapat dijadikan sebagai objek jaminan semakin beraneka ragam. Maka terbentuknya salah satu lembaga jaminan yaitu fidusia. Lembaga jaminan fidusia tersebut menjaminkan semua kebendaan yang bergerak maupun berwujud dan tidak berwujud serta kebendaan tidak bergerak yang tidak terikat dengan hak tanggungan. Munculnya lembaga jaminan fidusia ini diatur pada Undang-Undang Nomor 42 Tahun 1999 tentang Jaminan Fidusia (Undang-Undang Jaminan Fidusia). Dengan adanya lembaga jaminan fidusia ini, maka semakin banyak objek benda yang dapat dijadikan sebagai jaminan dalam rangka untuk mendapatkan fasilitas kredit dari lembaga perbankan.

Salah satu benda bergerak tidak berwujud yang dapat dijadikan objek jaminan pada lembaga jaminan fidusia yaitu Hak Cipta. Hak cipta merupakan salah satu bagian dari Hak Atas Kekayaan Intelektual (HKI). Pada umumnya pengertian HKI adalah hak memperoleh nilai ekonomis dari pikir yang menghasilkan suatu ciptakan yang berfaedah bagi seluruh masyarakat. Menurut pasal 16 ayat 3 Undang-Undang Republik Indonesia Nomor 28 Tahun 2004 tentang Hak Cipta (Undang-Undang Hak Cipta), Hak Cipta dapat dijadikan sebagai objek jaminan fidusia.

Perbankan di Negara Indonesia hingga saat ini belum dapat dilaksanakan mengenai hak cipta sebagai objek jaminan fidusia. Dikarenakan belum tersedia suatu lembaga yang dapat memberikan penilaian ekonomis kepada ciptaan yang dihasilkan oleh seorang seniman. Dikarenakan dasar hukum mengikat debitur dengan perjanjian kredit tidak kuat. Dan pada Undang-Undang Jaminan Fidusia hanya mengatur secara umum mengenai objek fidusianya. Sehingga terdapat ketidakjelasan mengenai objek yang dijadikan jaminan tersebut. Permasalahan tersebut timbul disebabkan oleh belum ada regulasi khusus tentang hak cipta sebagai objek jaminan.

Akan tetapi pada dunia praktek terdapat permasalahan hukum yang timbul mengenai hak cipta yang dapat dijadikan sebagai objek jaminan fidusia tersebut. Serta belum terlaksananya sebagaimana mesti peraturan perundang-undangan yang dikeluarkan oleh pemerintah. Jika dipandang 
dari pihak lembaga perbankan tersebut belum mengetahui bagaimana cara penerapan peraturan yang dikeluarkan oleh pemerintah. Seperti hal, pemberian nilai fasilitas pinjaman yang diberikan berdasarkan hak cipta yang dijadikan objek jaminan fidusia. Walaupun hak cipta tersebut memiliki nilai ekonomis sebagai telah tercantum pada peraturan yang berlaku tersebut.

Hak cipta sebagai objek jaminan fidusia belum tercantum pada pasal 46 tentang Peraturan Perbankan Indonesia Nomor 9/6/PBI/2007 tentang Perubahan Kedua atas Peraturan Perbankan Indonesia Nomor 7/2/PBI/2005 tentang Penilaian Kualitas Aktiva Bank Umum sehingga pihak perbankan belum dapat menerima sebagai agunan kredit.

Berdasarkan permasalahan hukum yang telah dipaparkan oleh penulis diatas maka penulis tertarik untuk melakukan penelitian mengenai "ANALISIS YURIDIS TERHADAP PENERAPAN HAK CIPTA SEBAGAI OBJEK JAMINAN FIDUSIA DALAM PEMBERIAN FASILITAS KREDIT PADA PERBANKAN DI KOTA BATAM."

\section{B. Metode Penelitian}

Penulis memakai beberapa metode penelitian dalam rangka mengetahui, mencari jawaban terhadap rumusan masalah yang diangkat pada penelitian ini. Pada penelitian ini menggunakan jenis penelitian aturan empiris.

Penelitian ini Penulis memperoleh data primer dari berasal yang akan terjadi wawancara Penulis secara eksklusif dengan beberapa narasumber yaitu lembaga keuangan, notaris serta advokat dan konsultan hukum. Dan mengenai data sekunder merupakan studi kepustakaan yang sumber data penelitian berasal dari catatan, buku maupun arsip yang telah atau belum dipublikasikan. Berdasarkan jenis data sekunder informasi yang digunakan untuk mendukung penelitian ini berupa landasan konseptual, yuridis dan teoritis. Informasi tersebut mengandung pendapat dari para ahli, hukum positif, doktrin hukum, dan untuk memperoleh berita pada bentuk ketetapan-ketetapan formal juga data yang berasal asal naskah resmi. mengenai data primer dan data sekunder yang dipergunakan dalam penelitian ini.

Berpedoman dengan jenis data terdiri dari dua yaitu data primer dan data sekunder digunakan oleh Penulis dalam memecahkan atau menjawab rumusan masalah yang diangkat dalam penelitian skripsi ini. Serta dipadukan dengan metode penelitian hukum empiris. Maka cara Penulis dalam teknik pengumpulan data yaitu berupa wawancara secara langsung dengan narasumber-narasumber yang memiliki kaitan dengan permasalahan yang sedang diteliti.

Tahap wawancara yang diterapkan oleh Penulis dalam penelitian ini dengan cara menyusun pertanyaan-pertanyaan terlebih dahulu. Pertanyaan yang disusun tersebut berhubungan dengan objek penelitian Penulis. Pihak 
yang diwawancarai oleh penulis secara langsung adalah lembaga perbankan (Bank Umum dan BPR), Notaris, Advokat dan Konsultan Hukum serta instansi pemerintahan yaitu Menkumham.

Selain Penulis melakukan tanya jawab secara langsung dengan narasumber bersangkutan, sumber sekunder Penulis merupakan himpunan informasi berasal dari studi kepustakaan, dan dalam penelitian ini Penulis juga menggunakan data-data dari hasil penelitian orang lain seperti jurnal, skripsi, tesis, dan lain-lain. Selain itu informasi-informasi dari hasil studi kepustakaan yang digunakan oleh Penulis berupa Materi hukum primer, sekunder dan tersier serta peraturan perundang-undangan. Untuk memperkuat argumen Penulis dalam penelitian ini.

Metode analisis data menggunakan analisis data deskriptif kualitatif. Deskriptif berarti bahwa data hasil penelitian ini dikumpulkan, diproses dan dijelaskan dalam bentuk uraian terperinci tentang interpretasi atau penafsiran data yang ada untuk mengungkap makna dan isi dari aturan hukum yang akan digunakan. Sebagai panduan atau referensi, berikan solusi untuk masalah hukum yang menjadi subjek penelitian ini. Meskipun kualitatif mengacu pada studi teori dan norma hukum yang terkandung dalam hukum dan peraturan yang berlaku dan dikembangkan di masyarakat. Tujuan dari metode analisis data adalah untuk mengetahui bagaimana elemen-elemen ini berinteraksi secara simbolis sehingga penelitian dapat sepenuhnya memahami informasi, data, fakta hukum, atribut, dan hubungan antara fenomena yang dihadapi.

Setelah fase analisis data selesai, hasil penelitian ilmiah akan ditulis secara deskriptif dengan menggambarkan dan menjelaskan informasi yang diperoleh dari pertanyaan dalam penelitian. Dari hasil ini, dapat disimpulkan bahwa ini adalah jawaban untuk pertanyaan yang diajukan dalam penelitian ini.

\section{Hasil Penelitian dan Pembahasan}

Bapak Soehendro pendapat bahwa fakta yang terjadi di lembaga perbankan di Kota Batam belum adanya penerapan hak cipta sebagai objek jaminan fidusia dalam dunia praktek lembaga keuangan. Dapat dikatakan bahwa kepedulian dan kesadaran masyarakat Indonesia atas hak cipta itu sendiri masih rendah. Dikarenakan sebagian besar dari masyarakat Indonesia masih menikmati atas hasil karya cipta seseorang dengan menggunakan situs yang ilegal.

Ciptaan-ciptaan yang terbentang lebar di situs ilegal diperoleh tanpa mendapatkan persetujuan dari pemilik atau pemegang dari hak cipta itu sendiri. Dengan kata lain secara tidak langsung tindakan tersebut merupakan tindak pidana pencurian. Akan tetapi masyarakat Indonesia tidak menyadari akan hal tersebut. Bahkan kebanyakan dari mereka cenderung membiarkan hal tersebut karena menganggap perbuatan itu bukan tergolong pencurian hak milik orang lain. 
Secara garis besar mempunyai perbedaan yang sangat signifikan antara hak cipta dengan hak milik kebendaan. Perbedaan pertama yaitu pencipta tetap tercantum pada hasil ciptaannya meskipun telah beralih ke pihak lain dikarenakan dalam hak cipta itu sendiri terkandung hak moral. Hal ini berbeda dengan pemilik atas hak milik kebendaan (contoh pemilik rumah) yang namanya otomatis berpindah ke pihak lain, apabila pemilik rumah melakukan transaksi terhadap rumahnya. Contoh lain pemilik atas hak cipta dapat membuat lisensi kepada beberapa pihak, sedangkan pemilik atas rumah hanya bisa memberi sewa atas rumahnya kepada satu pihak.

Penulis juga melaksanakan tanya jawab secara langsung dengan Rorif Desvyati, SH, MH selaku Kasubbid Pelayanan AHU dan KI Kanwil Menkumham Kepulauan Riau di Tanjung Pinang. Menurut pandangan dari Ibu Rorif penerapan hak cipta sebagai jaminan harus adanya lembaga appraisal dimana lembaga tersebut yang akan mengkaji dan menghitung atas sertifikat cipta yang dimiliki oleh pencipta, dengan mempertimbangan segala resiko. Dan lembaga appraisal yang akan memberikan rekomendasi kepada lembaga pembiayaan dalam hal ini berapa pinjaman yang diberikan untuk pihak pemilik sertifikat cipta atau pencipta.

Selain itu, Penulis juga mewawancarai Adolf Brelly Pangaribuan, Sarjana Hukum selaku Advokat dan Legal Consultant di Kota Batam. Beliau berpendapat bahwa hal-hal yang menjadi kendala atau hambatan dalam penerapan hak cipta sebagai objek jaminan fidusia adalah di Indonesia belum ada lembaga mekanisme penilaian dan pengikatan atas objek jaminan (hak cipta) ciptaan dan lisensi (hak memperbanyak) tersebut. Karena dengan melihat sisi ekonomis dan keuntungan yang dimiliki dengan ijin lisensi tersebut. Selain itu, belum ada lembaga keuangan yang mau menerima hak cipta sebagai objek jaminan fidusia terkait dengan regulasi dan batasan penilaian atas objek jaminan hak cipta itu sendiri.

Pendapat Bapak Adolf Penulis kutip bahwa yang menjadi kendala dan hambatan dalam penerapan hak cipta sebagai jaminan fidusia tidak diterapkan hingga sekarang bukan hanya sekedar tingkat kesadaran masyarakat Indonesia yang masih rendah yang telah dibahas oleh Penulis diatas. Selain itu masih ada hal-hal yang lain yaitu pertama belum ada lembaga mekanisme penilaian dan pengikatan atas objek jaminan (hak cipta) ciptaan dan lisensi itu sendiri.

Di negara Indonesia belum tersedia mekanisme penilaian atas suatu objek hak cipta itu sendiri. dengan kata lain suatu kebendaan yang akan dijadikan jaminan tidak bervaluasi apabila valuasinya jauh lebih rendah dari pinjamannya. Oleh karena itu lembaga keuangan akan memperhitungkan terlebih dahulu nilai ekonomi yang dimiliki dari objek kebendaan tersebut sebelum memberikan fasilitas kredit. 
Salah satu negara di Asia yang telah memiliki lembaga indikator penilai atas hak cipta yaitu Singapura. Intelectual Property Office of Singapore (IPOS) merupakan lembaga pengelola hak kekayaan intelektual di Singapura. IPOS memberikan mandat kepada enam bank antara lain DBS, Evia Capital Paetners, Oversea-Chinese Banking, OCBC, Resona Merchant Bank Asia dan UOB untuk menyalurkan pinjaman dalam bentuk jaminan atas hak cipta. IPOS juga memberikan bantuan biaya dalam hal penilaian aset hak cipta dan underwriting.

Kedua, belum ada pihak lembaga keuangan yang mau menerima hak cipta sebagai objek jaminan fidusia terkait dengan regulasi dan batasan penilaian atas objek jaminan hak cipta itu sendiri. dikarenakan berdasarkan peraturan Bank Indonesia itu sendiri hak cipta belum dimasukan sebagai dari salah satu agunan kredit. Oleh karena itu diperlukan ada regulasi atau revisi mengenai peraturan Bank Indonesia Nomor 14/15/PBI/2012 tentang jenis agunan kredit tepatnya pada pasal 43 tersebut.

Penulis tidak hanya mewawancarai pihak notaris dan pengacara, Penulis juga tidak lupa mewawancarai dari pihak lembaga keuangan salah satu hasil wawancara yang Penulis ambil adalah pandangan dari Jimi Heriza selaku Direktur Utama dari salah satu Badan Perkreditan Rakyat yang ada di Kota Batam. Beliau menyampaikan bahwa pihak dari lembaga keuangan selama ini hanya memberikan penilaian terhadap aset benda bergerak dan tidak bergerak. Yang dinilai berdasarkan keadaan fisik terhadap suatu jaminan dan faktor ekonomi atas aset tersebut ditinjau berdasarkan nilai pasar. Selain itu lembaga keuangan juga memiliki fungsi untuk menyalurkan kredit kepada masyarakat, dengan kata lain apabila membawa keuntungan bagi pihak bank maka akan diterima. Jadi apabila hak cipta tersebut diterapkan maka akan memberikan peluang bisnis bagi lembaga keuangan semakin berjaya. Tetapi ada permasalahan yang perlu tuntaskan untuk menjadi hak cipta tersebut sebagai peluang bisnis yaitu cara eksekusi dari hak cipta itu sendiri apabila sudah dijadikan objek jaminan fidusia.

Permasalahan ini terjawab dengan hasil wawancara dengan bapak aldof selaku advokat menyampaikan bahwa dapat dilakukan eksekusi dan peralihan hak jaminan fidusia bepedoman pada Pasal 29 Undang-Undang Jaminan Fidusia yang pelaksanaan eksekusi dan peralihan hak jaminan fidusia dalam Pasal tersebut dapat dilaksanakan dengan tiga cara yaitu pertama eksekusi berdasarkan titel eksekutorial melalui penetapan pengadilan, kedua parate eksekusi via pelelangan umum dan ketiga penjualan agunan dibawah tangan.

Penerapan hak cipta sebagai objek jaminan fidusia dalam dunia praktek dapat diterapkan dengan cara pasal agunan dalam perjanjian kredit tersebut terbagi menjadi dua yaitu agunan pokok dan agunan tambahan. Jadi sertifikat hak cipta tersebut dijadikan agunan tambahan sedangkan agunan pokoknya berupa hak milik kebendaan yang berwujud seperti 
rumah, mobil, motor dan lain-lain. Ini merupakan hasil wawancara Penulis berdasarkan pandangan dari Bapak Soehendro.

Penulis mengutip pandangan dari Dr. Cita Yustisia Serfiyani, SH, MH dari Buku Hak Kekayaan Intelektual sebagai Jaminan Kredit. Beliau menyatakan bahwa hak cipta dapat diikat dengan jaminan fidusia dengan melalui dua jenis pengikatan agunan yaitu agunan pokoknya berupa sertifikat hak cipta sedangkan agunan tambahannya berupa perjanjian lisensi atau perjanjian waralaba yang dapat memberikan penghasilan bagi pemegang hak cipta itu sendiri.

Pandangan dari Bapak Soehendro dengan Bu Cita tersebut dapat hak cipta sebagai jaminan fidusia dapat diterapkan dalam dunia praktek dengan catatan telah direvisi dan telah memasukan hak cipta sebagai salah satu agunan kredit pada Peraturan Bank Indonesia.

Hasil wawancara Penulis dengan Ibu Rorif Desvyati, SH, MH mengatakan bahwa Undang-Undang Jaminan Fidusia hanya mengatur kepada benda bergerak, sedangkan hak cipta merupakan benda bergerak tidak berwujud dimana dalam Undang-Undang Jaminan Fidusia tersebut pengaturannya tidak diatur secara signifikan. Yang di Undang-Undang Jaminan Fidusia hanya sebatas ruang lingkup dari kebendaan berwujud tersebut.

\section{Pelaksanaan dalam praktek mengenai hak cipta sebagai objek jaminan fidusia terhadap kredit perbankan di Kota Batam.}

Berpedoman pada hasil penelitian Penulis yang terpapar diatas dapat ditarik kesimpulan pelaksanaan dalam praktek mengenai hak cipta sebagai objek jaminan fidusia terhadap kredit perbankan di Kota Batam. Belum terkunjungi dilaksanakan hingga sekarang. Dan secara teori hak cipta dapat dijadikan sebagai objek jaminan fidusia sudah disahkan berdasarkan Pasal 16 ayat (3) Undang-Undang Hak Cipta.

Dasar hukum Pasal 1 ayat (1) dan (2) Undang-Undang Jaminan Fidusia, hak cipta merupakan benda yang tidak berwujud dan dapat dijadikan sebagai jaminan fidusia. Disamping itu hak kepemilikan atas hak cipta dapat dialihkan kepada pihak lain secara setengah atau sepenuhnya yang tercantum dalam Pasal 16 ayat (2) Undang-Undang Hak Cipta.

Pelaksanaan pengikatan hak cipta sebagai jaminan fidusia dapat diterapkan secara praktek juga. Dengan cara harus dibuat perjanjian fidusia berdasarkan akta notaris. Dan perjanjian fidusia yang telah dibuat tersebut harus didaftar ke Direktorat Administrasi Hukum Umum (untuk selanjutnya disebut Ditjen AHU) dan Kementerian Hukum dan HAM (untuk selanjutnya disebut Kemenkumham). Serta Ditjen AHU dan Kemenkumham sudah meningkatkan fasilitas untuk pendaftaran fidusia bisa melalui website yaitu https://fidusia.ahu.go.id/ 
Ditjen AHU dan Kemenkumham meningkatkan fasilitas pelayanan kepada masyarakat untuk memberikan kemudahan kepada setiap orang melakukan pendaftaran jaminan fidusia. Pada situs tersebut pendaftaran fidusia dapat dilaksanakan oleh Notaris, Korporasi, Ritel maupun Kanwil.

Pengikatan agunan hak cipta melalui akta notaris terdapat dua jenis agunan yang harus diikat antara lain :

a. Sertifikat hak cipta (sebagai agunan pokok); dan

b. Perjanjian lisensi atau perjanjian waralaba yang dapat menghasilkan royalti (sebagai agunan tambahan).

Hak cipta diikat dengan jaminan fidusia yang menjadi pegangan bagi pihak lembaga keuangan adalah sertifikat hak ciptanya. Dan sertifikat hak cipta itu sendiri tidak memiliki nilai ekonomi. Sertifikat hak cipta tersebut akan memiliki nilai ekonomi apabila pemegang hak cipta membuat perjanjian lisensi dengan pihak lain dan mendapatkan royalti.

Pemegang hak cipta dikemudian hari ingin melakukan tindakan berdasarkan hak eksekutifnya. Seperti contohnya membuat perjanjian lisensi atau perjanjian waralaba maka diperlukan persetujuan terlebih dahulu dari pihak lembaga keuangan. Dikarenakan pada dasarnya dalam membuat perjanjian lisensi dan perjanjian waralaba dibutuhkan adanya bukti sertifikat hak cipta asli yang dipegang oleh pihak lembaga keuangan tersebut.

Dasarnya hak cipta wajib didaftarkan kepada Ditjen AHU dan Kemenkumham apabila pemegang hak cipta ingin melakukan perbuatan hukum atas ciptaannya seperti dijaminkan, dialihkan atau dilisensikan.

Tata cara perolehan hak cipta pada prinsipnya dapat diperoleh ketika ciptaan tersebut diwujudkan. Hal ini berbeda dengan karya intelektual lain yang mensyaratkan perolehan haknya dengan mendaftarkan. Hal ini bukan berarti ciptaan tidak perlu didaftarkan. Ciptaan yang didaftarkan mempunyai fungsi sebagai bukti bahwa pencipta berhak atas ciptaan.

Mengenai debitur wanprestasi terhadap perjanjian yang telah disepakati atau tidak sanggup membayar pinjamannya, maka kreditur memiliki wewenang untuk eksekusi hak cipta berdasarkan hukum jaminan fidusia yang berlaku pada Pasal 29 ayat (1) Undang-Undang Jaminan Fidusia.

Menurut pandangan Penulis akan lebih mudah menerapkan hak cipta sebagai agunan kredit dalam dunia praktek lebih mudah untuk diterapkan berdasarkan pandangan dari Bapak Soehendro di hasil penelitian diatas. Yang menjadi agunan pokok adalah hak milik 
kebendaan yang berwujud seperti rumah, mobil, motor sedangkan untuk agunan tambahannya berupa sertifikat hak cipta.

Dikarenakan dalam masyarakat Indonesia sekarang ini untuk hak cipta belum dipandang baik. Sehingga nilai ekonomi dari hak cipta itu sendiri masih rendah. Sehingga bagi pencipta-pencipta yang baru terjun dalam menciptakan suatu hal yang baru. Untuk memperoleh pinjaman dari bank maka diperlukan suatu aset yang lebih bernilai ekonomi dijadikan agunan pokoknya untuk menjadi backup dari agunan tambahannya.

Berbeda hal pencipta yang hasil ciptaan telah beredar secara luas dipasaran dan laku. Dan ingin meningkatkan penjualan hasil ciptaan dengan cara memperbanyak ciptaannya. Dan membutuhkan modal untuk melakukannya tersebut. maka yang dapat dijadikan sebagai jaminan fidusia berupa sertifikat hak cipta. Yang agunan pokoknya berupa sertifikat hak cipta sedangkan agunan tambahannya merupakan perjanjian lisensi atau perjanjian waralaba yang menghasilkan royalti bagi pemegang hak cipta.

Mengenai eksekusi terhadap hak cipta sebagai agunan kredit pada lembaga keuangan berdasarkan pandangan Penulis hal tersebut dapat diterapkan dengan cara membuat perjanjian antara pencipta yang bertindak selaku debitur dan lembaga keuangan selaku kreditur. dimana perjanjian yang dibuat para pihak harus memenuhi unsurunsur syarat sah perjanjian kredit yang dasar hukumnya tercantum dalam Pasal 1320 KUH Perdata.

Poin yang paling penting adanya kesepakatan antara pencipta dengan lembaga keuangan. Yang dalam perjanjian kredit mencantum mengenai hal-hal apabila debitur yaitu pencipta wanprestasi terhadap perjanjian yang telah disepakati maka kreditur memiliki hak atas cipta tersebut. Berlandasan hukum yang tercantum pada Pasal 16 sampai dengan Pasal 18 Undang-Undang Hak Cipta.

Menguatkan perjanjian kredit tersebut hal lain yang perlu dilakukan yaitu membuat akta notaris jaminan fidusia yang objek jaminannya berupa sertifikat hak cipta dan perjanjian lisensi dan dikuatkan dengan mendaftarkan ke pendaftaran fidusia. Objek agunan mengenai perjanjian lisensi tersebut berguna untuk jika debitur wanprestasi maka kreditur memiliki hak untuk menikmati atas hak ekonomi dari ciptaan tersebut. Diatur dalam Pasal 15 dan Pasal 20 Undang-Undang Jaminan Fidusia.

Istilahnya jika seorang pencipta melakukan pinjaman dengan lembaga keuangan dengan agunan hak cipta. Maka hak cipta atas ciptaan baik secara hak moral dan hak ekonomi telah dijadikan sebagai objek agunan kreditnya. Jadi apabila pencipta tersebut tidak memenuhi kewajibannya sebagai debitur maka seluruh hak atas ciptaannya menjadi milik lembaga keuangan. Sehingga dikemudian 
hari apabila pihak lembaga keuangan ingin melakukan hal mengenai mengalihkan, menjual, memperbanyak, atau mengubah atas hak cipta tersebut tidak diperlukan memberitahukan kepada pencipta. Karena pihak perbankan yang memiliki hak sepenuhnya atas hak cipta tersebut.

Hak cipta tersebut didaftarkan oleh pencipta hanya sekedar untuk kejelasan dalam hal kepemilikan atas ciptaan. Jika ada pihak lain yang ingin memakai atau menikmati atas karya ciptaannya perlu mendapatkan persetujuan atau izin dari pencipta. Apabila hak cipta tersebut telah diagunkan kepada lembaga keuangan yang memiliki hak penuh atas hak cipta tersebut adalah lembaga keuangan. Karena pencipta telah menyerahkan hak cipta sepenuhnya kepada lembaga keuangan saat penandatanganan perjanjian kredit serta akta-akta pendukung lainnya.

\section{Hambatan yang dialami dalam penerapan hak cipta sebagai objek} jaminan fidusia di Kota Batam.

Pengertian Hak Cipta berdasarkan ketentuan Pasal 1 angka 1 Undang-Undang Hak Cipta. Hak cipta mencakup dua jenis hak, moral dan ekonomi. Hak moral adalah hak untuk selalu terikat pada ciptaan yang diciptakan oleh pencipta, dan hak ekonomi adalah hak untuk memberikan manfaat ekonomi bagi pencipta.

Hak eksklusif adalah hak yang hanya tersedia untuk pencipta, sehingga tidak ada orang lain yang dapat mengambil keuntungan dari hak-hak ini tanpa izin dari pencipta. Pemilik hak cipta yang bukan pencipta hanya memiliki bagian dari hak eksklusif dalam bentuk hak ekonomi.

Berdasarkan Pasal 4 Undang-Undang Hak Cipta maka pemegang hak cipta mempunyai hak eksklusif untuk menikmati hak ekonominya berupa royalti dari hasil ciptaan, dengan cara melisensikan karya ciptaannya kepada pihak lain. Akan tetapi yang menjadi persoalan hingga saat ini masih banyak hambatan yang dialami oleh pemegang hak cipta dalam hal kesulitan memperoleh modal untuk memperluas usaha seperti memperbanyak karya ciptaannya.

Persoalan yang dialami oleh pencipta yaitu barang berharga dari pencipta yaitu hak cipta tersebut tidak dapat dijadikan sebagai agunan kredit di lembaga keuangan. Padahal secara lahiriah hak cipta itu merupakan kebendaan tidak berwujud yang berharga dan dapat dijadikan sebagai jaminan kredit.

Hak cipta belum dapat diterima oleh lembaga keuangan dikarenakan tidak termasuk dalam salah satu jenis agunan yang dapat dijadikan agunan bagi lembaga keuangan dalam pemberian fasilitas kredit. Lembaga keuangan bertindak dalam hak menyalurkan kredit untuk mensejahterakan rakyat berdasarkan salah satu tujuan negara 
Indonesia tersebut bertindak berdasarkan peraturan yang dikeluarkan oleh Bank Indonesia (BI) sekarang Otoritas Jasa Keuangan (OJK).

Sudut pandang hukum jaminan kebendaan Hak Cipta dapat dijadikan jaminan utang melalui skema fidusia. Untuk dijadikan jaminan fidusia masih terhambat dengan Peraturan Bank Indonesia Nomor 14/15/PBI/2012 tentang jenis agunan kredit.

Seharusnya hak cipta dimasukan pada Peraturan Bank Indonesia tersebut. Dikarenakan hak cipta telah memenuhi syarat sebagai objek jaminan fidusia. Yang terdapat pada Pasal 1 angka 4 Undang-Undang Jaminan Fidusia yang membahas mengenai pengertian benda.

Hak cipta dapat dijadikan sebagai objek jaminan utang melalui skema Fidusia tetapnya pada Pasal 16 ayat (3) Undang-Undang Hak Cipta. Seiring dengan kemajuan teknologi untuk meningkatkan pertumbuhan ekonomi sudah sangat mudah. Banyak negara-negara maju yang memiliki lembaga penilai aset hak cipta dalam bentuk situs internet, salah satu contohnya Negara Denmark. Nama situs lembaga penilai aset hak cipta Denmark adalah Danish Patent and Trademark Office (DPTO).

Situs DPTO tersebut pemilik hak cipta dapat mendaftarkan hasil ciptanya untuk dialihkan atau dilisensikan. Selain itu situs tersebut juga memberikan informasi bagi pemilik hak cipta mengenai harga atas ciptaannya dalam pasaran. Untuk hak cipta yang ingin dijadikan agunan kredit di lembaga keuangan di Dermark tersebut. lembaga penilai aset hak cipta yang digunakan oleh pencipta harus yang telah terdaftar dan tersertifikat.

Di Indonesia masih belum ada lembaga seperti penentuan nilai hak cipta tersebut. yang tugas utama dari lembaga tersebut untuk menentukan nilai ekonomi dari suatu karya cipta. Indonesia perlu untuk membuat lembaga penilai aset hak cipta untuk meningkatkan pertumbuhan ekonomi.

Membentuk lembaga penilai aset hak cipta, lembaga tersebut harus tersertifikasi dan terakreditasi oleh DJKI. Harus terdaftar di BI selaku otoritas pasar uang dan OJK selaku otoritas pasar modal dan lembaga jasa keuangan.

Pembentukan lembaga penilai untuk menentukan dalam hal valuasi dari hak cipta itu sudah sangat mudah. Dan bagi pihak pencipta untuk mendapatkan pinjaman dari lembaga keuangan juga bisa. Karena lembaga penilai tersebut telah ada disetujui oleh BI sekarang OJK. Dan dapat mengambil contoh dari negara Denmark tersebut.

Pengajuan kredit oleh pencipta dalam hal ini agunan kredit berupa hak cipta harus beberapa syarat yang harus dipenuhi sebelum pihak lembaga keuangan menentukan jumlah fasilitas kredit yang diberikan 
kepada pencipta. Salah satu persyaratan yang Penulis ambil contohnya ada pengajuan kredit di Bank DBS yaitu :

a. Perusahaan harus menetap di Singapura;

b. Tidak diperuntukan bagi badan usaha perseorangan atau kemitraan;

c. Hak cipta sudah terdaftar dan bersertifikat yang akan dijadikan agunan kredit;

d. Pengajuan kredit harus pencipta dari hak cipta itu sendiri tidak boleh berdasarkan kuasa;

e. Untuk bukti evaluasi hak cipta, calon penerima kredit harus menyerahkan bukti evaluasi perusahaan yang kompeten di bidang hak cipta.

Hambatan terakhir adalah Undang-Undang Jaminan Fidusia harus direvisi juga karena dalam peraturan tersebut tidak mengatur secara signifikan mengenai objek kebendaan bergerak yang tidak berwujud. Yang mana hanya sebatas ruang lingkup dari kebendaan berwujud tersebut.

Menurut Penulis secara keseluruhan yang menjadi hambatan dalam penerapan hak cipta sebagai agunan kredit yang pertama adalah perlu diubah Pasal 43 Peraturan Bank Indonesia Nomor 14/15/PBI/2012 tentang jenis agunan kredit mengenai jenis kebendaan yang dapat dijadikan agunan kredit. Kedua, lembaga valuasi aset atas hak cipta. Dalam membentuk lembaga harus terakreditasi dan tersertifikat oleh BI sekarang OJK, dan terakhir revisi UUJF menjadi lebih signifikan pengaturannya terhadap objek kebendaan bergerak yang tidak berwujud. Mengenai syarat-syarat pengajuan kredit dengan agunan kreditnya hak cipta tersebut akan lahir secara langsung dengan telah teratasi hambatan-hambatan yang telah dipaparkan oleh Penulis diatas.

Penerapan hak cipta sebagai agunan kredit ini belum adanya kepastian hukum menurut Penulis. Dikarenakan Pasal 16 ayat (3) Undang-Undang Hak Cipta tersebut dikeluarkan akan tetapi tidak ada lembaga keuangan yang melaksanakan peraturan tersebut. Disebabkan sejak dikeluarkan peraturan tersebut masih belum ada tindakan pemerintah lebih lanjut mengenai penyelesaian permasalahan yang dihadapi dalam penerapan peraturan hak cipta ini.

Pengaturan yang terdapat dalam Pasal 16 ayat (3) UndangUndang Hak Cipta terkait dan bahkan bergantung dengan undangundang yang lain seperti yang disebutkan dalam Pasal 16 ayat (4) Undang-Undang Hak Cipta. Peraturan perundang-undangan yang paling dekat adalah Undang-Undang Jaminan Fidusia. 
Disisi lain pengaturan hukum mengenai hal cipta sebagai jaminan fidusia ini masih belum lengkap. Selain itu tidak ada tindakan Ditjen AHU dan Kemenkumham serta BI sekarang OJK bekerja sama dalam hal melaksanakan sosialisasi dengan pihak lembaga keuangan dan notaris untuk menyelesaikan permasalahan yang dihadapi ini. Bahkan pihak lembaga keuangan pun tidak mengetahui bahwa adanya peraturan yang mengatur hak cipta dapat dijadikan sebagai agunan kredit.

Maka perlu adanya pembaharuan mengenai peraturan tersebut agar pihak lembaga keuangan seperti bank umum dan BPR dapat melaksanakan peraturan tersebut sesuai dengan ketentuan peraturan perundang-undangan yang ada. Dengan direvisi peraturan tersebut maka pihak lembaga keuangan juga mendapatkan kemanfaatan dari peraturan tersebut dan pertumbuhan ekonomi di Indonesia semakin meningkat karena bisnis perbankan dalam hal menyalurkan kredit oleh pihak lembaga keuangan lancar disebabkan jenis agunan kredit bertambah yaitu karya cipta.

Peraturan BI yang mengatur tentang agunan kredit perlu direvisi dikarenakan dalam peraturan tersebut belum mengatur dan memasukan hak cipta salah satu agunan yang dapat dijadikan sebagai jaminan kredit. Sedangkan Undang-Undang Jaminan Fidusia perlu direvisi disebabkan pengaturan pada Undang-Undang tersebut masing kurang signifikan disebabkan hanya mengatur ruang lingkup objek jaminan fidusia untuk objek benda bergerak tidak berwujud tersebut.

Peraturan yang mengatur mengenai perlindungan dari suatu hak cipta sudah ada akan tetapi untuk penegakan hukum atas hak cipta itu sendiri masih belum ada. Sehingga kesadaran masyarakat terhadap hak cipta itu rendah. Untuk memicu kesadaran itu maka diperlukan penegakan hukum tersebut dijalankan bersama dengan revisi peraturan yang terkait tersebut. Sehingga akan menciptakan suatu terobosan bagi Indonesia yang dimana pertumbuhan usaha kecil menengah bertumbuh pesat dikarenakan para pencipta dapat memperoleh modal dari lembaga keuangan. Dengan jaminannya adalah sertifikat hak cipta. serta mereka akan terus menghasilkan karya yang baru dari modal yang diperoleh tersebut.

\section{Kesimpulan}

1. Penerapan hak cipta sebagai agunan kredit di Kota Batam masih terkendala. Dikarenakan hak cipta belum tercantum sebagai agunan kredit pada Pasal 43 Peraturan Bank Indonesia 14/15/PBI/2012 tentang Peraturan Perbankan Indonesia Nomor 9/6/PBI/2007 tentang Perubahan Kedua atas Peraturan Perbankan Indonesia Nomor 7/2/PBI/2005 tentang Penilaian Kualitas Aktiva Bank Umum. Dan 
pengaturan objek benda bergerak tidak berwujud pada UndangUndang Jaminan Fidusia masih belum signifikan. Selain itu belum adanya lembaga penilaian atau valuasi atas aset hak cipta itu sendiri.

2. Mengenai Undang-Undang Hak Cipta pada Pasal 16 ayat 3 yang berbunyi hak cipta dapat dijadikan objek jaminan fidusia. Dan syaratsyarat dari hak cipta sebagai objek agunan kredit sudah terpenuhi dan dapat diikat dengan dasar hukum jaminan fidusia.Dikarenakan hak cipta merupakan benda bergerak yang tidak berwujud. Akan tetapi kepastian hukum mengenai undang-undang tersebut belum ada. Disebabkan pengaturan undang-undang tersebut belum lengkap masih banyak harus diatasi atau dibentuk peraturan-peraturan yang baru untuk mendukung penerapan hak cipta sebagai agunan kredit dalam lembaga keuangan ini. 


\section{Daftar Pustaka}

\section{Buku}

Andreas Albertus. Hukum Fidusia. Malang: Selaras, 2010.

Arikunto. Prosedur Penelitian; Suatu Pendekatan Praktek. Jakarta: Reneka Cipta, 2002.

Asikin zainal. Pengantar Tata Hukum Indonesia. Jakarta: Rajawali Press, 2012.

Gunawan Widjaja. Jaminan Fidusia. Jakarta: PT. RajaGrafindo Persada, 2000.

Gunawan Widjaya dan Ahmad Yani. Jaminan Fidusia. Jakarta: Raja Grafindo Persada, 2001.

Hermansyah. Hukum Perbankan Nasional Indonesia. Jakarta: Kencana, 2007.

H. OK. Saidin. Aspek Hukum Hak Kekayaan Intelektual (Intellectual Property Rights). Depok: PT. RajaGrafindo Persada, 2015.

Irawan Soehartono. Metode Penelitian Sosial; Suatu Teknik Penelitian Bidang Kesejahteraan Sosial dan ilmu Sosial lainnya. Bandung: Remaja Rosda Karya, 2002.

J. Satrio. Hukum Jaminan Hak Jaminan Kebendaan. Bandung: Citra Aditya Bakti, 2002.

M. Yahya Harahap. Segi-segi Hukum Perjanjian. Bandung: Alumni,1986.

Mariam Darus Badrulzaman. Perjanjian Kredit Bank. Bandung: Alumni, 1989.

Muhammad Djumhana. Hukum Perbankan di Indonesia. Bandung: Citra Aditya Bakti, 2000.

Peter Mahmud Marzuki. Pengantar Ilmu Hukum. Jakarta: Kencana, 2008.

Purwahid Patrik dan Kashadi. Hukum Jaminan. Semarang: Universitas Diponegoro, 2006.

Riduan Tobink dan Bill Nikholaus. Kamus Istilah Perbankan. Jakarta: Atalya Rileni Sudeco, 2003.

Riduan Syahrani. Rangkuman Intisari Ilmu Hukum. Bandung: Citra Aditya Bakti, 1999.

Ronald Saija dan Roger F.X.V. Letsrin. Buku Ajar Hukum Perdata. Yogyakarta: Deepublish, 2016.

Soerjono Soekanto dan Sri Mamudji. Penelitian Hukum Normatif Suatu Tinjauan Singkat. Jakarta: RajaGrafindo Persada, 2003. 
Suyud Margono. Hukum Hak Cipta Indonesia Teori Dan Analisis Harmonisasi Ketentuan World Trade Organization (WTO)-TRIPs Agreement, ed. Risman Sikumbang. Bogor: Ghalia Indonesia, 2010 .

Wiryono Projodikoro. Azas-azas Hukum Perjanjian. Jakarta: Sumur Bandung, 1989.

\section{Peraturan/Undang-Undang}

Indonesia, Undang-undang Nomor 10 Tahun 1998 tentang Perubahan atas Undang-undang Nomor 7 tahun 1992 tentang Perbankan.

Indonesia, Undang-Undang Nomor 42 tahun 1999 tentang Jaminan Fidusia.

Kitab Undang-Undang Hukum Perdata [Burgerlijk Wetboek]. Diterjemahkan oleh Subekti dan R. Tjitrosudibio. Jakarta : Pradnya Paramita, 2004.

Indonesia, Peraturan Perbankan Indonesia tentang Perubahan Kedua atas Peraturan Perbankan Indonesia Nomor 7/2/PBI/2005 tentang Penilaian Kualitas Aktiva Bank Umum, PBI No.9/6/PBI/2007

Indonesia, Undang-Undang Nomor 28 tahun 2014 tentang Hak Cipta.

\section{Internet}

http://eprints.perbanas.ac.id/67/4/BAB\%20II.pdf, diunduh 11 November 2018.

https://ngobrolinhukum.wordpress.com/2013/02/05/memahami-kepastiandalam-hukum/, diunduh 28 Juli 2019.

https://www.coursehero.com/file/p737nnj/Kredit-berasal-dari-kata-Italiacredere-yang-mempunyai-arti-kepercayaan-yaitu/, diunduh 22 Juli 2019.

https://www.wawasanpendidikan.com/2017/09/Kredit-Pengertian-UnsurUnsur-Fungsi-Tujuan-Jenis-Jenis-serta-Prinsip-Prinsip-Kredir.html, diunduh 28 Juli 2019.

http://eprints.uny.ac.id/8968/3/BAB\%202\%20-09409131003.pdf, diunduh 28 Juli 2019.

http://repository.usu.ac.id/bitstream/handle/123456789/66700/Chapter\%20

III-IV.pdf?sequence=2\&isAllowed=y, diunduh 28 Juli 2019.

http://journal.unisla.ac.id/pdf/15112013/5.pdf, diunduh 3 Juni 2019.

http://diva-yana.blogspot.com/2014/12/penelitian-hukum-empiris.html, diunduh 2 Juni 2019. 